University of Nebraska - Lincoln

DigitalCommons@University of Nebraska - Lincoln

Faculty Publications: Department of

Entomology

Entomology, Department of

2006

\title{
Effects of Insect Herbivory on Physiological and Biochemical (Oxidative Enzyme) Responses of the Halophyte Atriplex subspicata (Chenopodiaceae)
}

P. D. Nabity

University of Nebraska-Lincoln

Tiffany Heng-Moss

University of Nebraska-Lincoln, thengmoss2@unl.edu

Leon G. Higley

University of Nebraska-Lincoln, Ihigley1@unl.edu

Follow this and additional works at: https://digitalcommons.unl.edu/entomologyfacpub

Part of the Entomology Commons

Nabity, P. D.; Heng-Moss, Tiffany; and Higley, Leon G., "Effects of Insect Herbivory on Physiological and Biochemical (Oxidative Enzyme) Responses of the Halophyte Atriplex subspicata (Chenopodiaceae)" (2006). Faculty Publications: Department of Entomology. 270.

https://digitalcommons.unl.edu/entomologyfacpub/270

This Article is brought to you for free and open access by the Entomology, Department of at DigitalCommons@University of Nebraska - Lincoln. It has been accepted for inclusion in Faculty Publications: Department of Entomology by an authorized administrator of DigitalCommons@University of Nebraska - Lincoln. 


\title{
Effects of Insect Herbivory on Physiological and Biochemical (Oxidative Enzyme) Responses of the Halophyte Atriplex subspicata (Chenopodiaceae)
}

\author{
P. D. NABITY, T. M. HENG-MOSS, ${ }^{1}$ AND L. G. HIGLEY \\ Department of Entomology, University of Nebraska, 202 Plant Industry, Lincoln, NE 68583-0816
}

Environ. Entomol. 35(6): 1677-1689 (2006)

\begin{abstract}
Physiological responses of the halophyte, Atriplex subspicata Nutt. Rydb., to defoliation injury were evaluated through a series of experiments measuring plant gas exchange, fluorometry, and enzyme activity. Leaves exposed to simulated insect herbivory exhibited reductions in photosynthesis, stomatal conductance, and transpiration. Carboxylation efficiency, maximum assimilation, and $\mathrm{CO}_{2}$ compensation were also negatively associated with mechanical leaf injury. Insect injury by a herbivore generalist, Spilosoma virginica, also reduced photosynthesis and carboxylation efficiency within the saturated spectrum of $\mathrm{A} / \mathrm{C}_{\mathrm{i}}$ response curves. Initially, declines in photosynthesis occurred because of transient stomatal limitations. However, after time, mesophyll limitations impaired photosynthesis and the plant's ability to compensate for injury. Fluorescence data and light assimilation responses indicated that defoliation did not play a role in limiting light reactions of photosynthesis. Enzyme analyses showed increased peroxidase activity with insect injury, suggesting the need for future characterization of oxidative enzymes, which have been associated with traits of resistance. Overall, we found a salt-tolerant plant to be susceptible to insect herbivory through a reduction in the efficiency of the plant to allocate energy resources. If salt tolerance comes at the cost of susceptibility to biotic interference, natural occurring halophytes or plants with transgenic salt tolerance may be at risk for heightened deleterious response to insect herbivory.
\end{abstract}

KEY WORDS salt tolerance, mesophyll limitations, peroxidase, plant-insect interactions

Saline wetland habitats are home to a wide array of unique flora and fauna. Atriplex subspicata is an annual forb that occurs coastally and throughout the western United States, growing in disturbed remnant saline soil patches, alkaline ditches, and stream banks where saline seeps constantly alter the abiotic environment. Because of the paucity of data on how halophytes, including Atriplex species, respond to insect herbivory, there is a need for understanding potential effects of herbivory on salt-tolerant plants.

Saline habitats are extremely stressful environments to the organisms inhabiting them. Halophytes have built-in mechanisms that give them an advantage over nonhalophytes in saline environments. The genus Atriplex contains a wide variety of salt-tolerant species with varying saline optima $(6-233 \mathrm{mM} \mathrm{NaCl})$ (Flowers et al. 1977); the genus also includes both $\mathrm{C}_{3}$ and $\mathrm{C}_{4}$ photosynthetic pathways present among differing species (Osmond et al. 1980). A number of studies have documented the effects of abiotic influence (e.g., temperature, salinity, photoperiod) on germination and plant zonation (Noe and Zedler 2000, 2001). Ungar (1996) examined the response of A. patula to increased salinity across development stages and

\footnotetext{
${ }^{1}$ Corresponding author, e-mail: thengmoss2@unl.edu.
}

showed decreased germination, concentrated ions in tissues, and increased ash content. Atriplex patula also showed greater selenium uptake relative to 30 other Atriplex lines (Vickerman et al. 2002) and increased uptake under irrigation (Wu et al. 1993). Irrigation decreased biomass, possibly because of decreased competitive ability among neighboring glycophytes (nonsalt tolerant) or selenium toxicity (Wu et al. 1993).

In examinations of halophyte photosynthesis, Atriplex species responded diversely to abiotic stress from saline conditions. In general, these studies have indicated that photosynthesis and subsequent growth are positive within the optimal salinity ranges but decrease outside these optima (Pearcy and Ustin 1984, Plaut et al. 1991, Glenn and Brown 1998). However, halophytes are subject to more than abiotic interference and must survive biotic interactions also.

Few studies of Atriplex, however, have evaluated responses to biotic influences (e.g., herbivory, competition), and current data are limited to evaluations of competition, large scale herbivory (grazing), granivory (seed predation), and their combinations (Ungar 1998). Recent work done on foliar herbivory or arthropod injury at the leaf level by Rand (1999, $2000,2004)$ focused on ecological interactions and not the effects on plant physiology. Cibils et al. (1998) 
reviewed plant-herbivore relations of Atriplex and consequences of such interactions, but again did not address plant response at a physiological level. Vickerman et al. (2002) tested the interaction between A. patula and beet armyworm, but evaluated the system from the perspective of insect survivability and not plant response.

Another area of recent focus has been on the enzymatic responses of plants to abiotic and biotic stress. Several studies have found the activity of oxidative enzymes, including peroxidase, increased under herbivory (Felton et al. 1994, Tscharntke et al. 2001, Roitto et al. 2003, Allison and Schultz 2004, Heng-Moss et al. 2004). In the only examination of oxidative enzyme activity in Atriplex, Wang et al. (1997) showed peroxidase presence increased with increasing salinity but did not characterize the activity level or isozyme profiles.

Currently, there are no comprehensive studies investigating the impact of insect herbivory on Atriplex plant species from an ecophysiological perspective. Consequently, our objective was to characterize the ecophysiology of the $\mathrm{C}_{3}$ plant A. subspicata within an inland saline wetland and under insect herbivore pressure. Especially, our goal was to document changes in A. subspicata photosynthesis, fluorescence, and oxidative stress-related enzymes in response to different forms of leaf injury.

\section{Materials and Methods}

Site Description. The Eastern saline wetlands of Lancaster County, NE, are host to unique species of aquatic, salt flat, and transitional plants, yet are defined by select indicator species. Indicator species as denoted by Farrar and Gersib (1991) include A. subspicata, commonly referred to as spearscale. Habitat disappearance has isolated stands of A. subspicata to spots along the Little Salt Creek. As a transitional plant, it is found between encrusted salt flats and meadow grasses surrounding water seeps where saline concentrations are weaker. Two sites were selected for field measures of A. subspicata photosynthesis. In 2000 , field measures were taken on plants located north of Lincoln, $\mathrm{NE}\left(40^{\circ} 85^{\prime}\right.$ lat, $96^{\circ} 75^{\prime}$ long), just west of Little Salt Creek at Arbor Lake Wildlife Management Area (WMA). For this study, we used plants within a transitional zone in the northeastern corner of the salt marsh. In 2004, field measures of photosynthesis and fluorometry occurred along Little Salt Creek, $\approx 13 \mathrm{~km}$ northwest of Arbor Lake WMA, along the west side of the salt flat.

Gas Exchange Parameters. All measures of photosynthesis were made using a LICOR LI-6400 portable photosynthesis meter (LI-COR Biosciences, Lincoln, $\mathrm{NE}$ ) with attached $\mathrm{CO}_{2}$ regulator and artificial light source (including both red and blue light to ensure proper stomatal response to changing light intensity). For plant surveys, a set $\mathrm{CO}_{2}$ concentration was passed over a known area $\left(\mathrm{cm}^{2}\right)$ of leaf tissue and analyzed by an infrared gas analyzer (IRGA). Remaining $\mathrm{CO}_{2}$ was referenced to the known concentration and, using an algorithm adapted from von Caemmerer and Farquhar (1981), net photosynthetic assimilation $\left(\mathrm{P}_{\mathrm{n}}\right)$ was determined. Assimilation was based on a photosynthetically active radiation (PAR) of $1800 \mu \mathrm{mol}$ photons $/ \mathrm{m}^{2} / \mathrm{s}$. We also set a constant temperature equal to the initial ambient temperature, which ranged from 26 to $36^{\circ} \mathrm{C}$, depending on experiment (and ambient conditions). Relative humidity remained constant by regulating machine airflow rate to track initial ambient RH. Light curves were produced by subjecting the leaf to constant $\mathrm{CO}_{2}\left(\mathrm{C}_{\mathrm{a}}=400 \mathrm{ppm}\right)$ along a prescribed range of PAR values $(0-2,400 \mu \mathrm{mol}$ quanta $/ \mathrm{m}^{2} / \mathrm{s}$ ). The assimilation/intercellular $\mathrm{CO}_{2}$ or $\mathrm{A} / \mathrm{C}_{\mathrm{i}}$ curves were produced by subjecting the leaf to constant PAR (1800 $\mu \mathrm{mol}$ quanta $\left./ \mathrm{m}^{2} / \mathrm{s}\right)$ and a prescribed series of $\mathrm{CO}_{2}$ values $\left(\mathrm{C}_{\mathrm{a}}=400,300,200,100\right.$, $50,400,400,600,800,1,000 \mathrm{ppm})$. In greenhouse experiments, the IRGA measurement chamber was modified to adjust for leaf areas $<6 \mathrm{~cm}^{2}$. For all other experiments, remaining (uninjured) leaf tissue completely filled the chamber $\left(6 \mathrm{~cm}^{2}\right)$. Gas exchange parameters measured included net photosynthesis $\left(\mathrm{P}_{\mathrm{n}}\right)$, stomatal conductance $\left(\mathrm{g}_{\mathrm{s}}\right)$, intercellular $\mathrm{CO}_{2}\left(\mathrm{C}_{\mathrm{i}}\right)$, and transpiration $(\mathrm{E})$.

Stomatal limitations were calculated following the interpretations of Farquhar and Sharkey (1982) and Sharkey (1985). For a measure of stomatal limitation, we compared the difference between assimilation under infinite conductance (potential assimilation if $\mathrm{C}_{\mathrm{a}}$ $=\mathrm{C}_{\mathrm{i}}$ ) to the assimilation under limited conductance (normally occurring resistance) using a best fit nonlinear regression for each response curve. Comparisons between treatments where the difference is larger suggest assimilation is reduced more by limitations in diffusion (stomata).

Fluorometry parameters were measured on lightadapted leaves using the kinetic program on a modulated chlorophyll fluorometer (model OS5-FL; OptiSciences, Tyngsboro, MA). Parameters examined included variable fluorescence $\left(\mathrm{F}_{\mathrm{v}}{ }^{\prime}=\right.$ minimal fluorescence $\left[\mathrm{F}_{\mathrm{o}}{ }^{\prime}\right]-$ maximal fluorescence $\left[\mathrm{F}_{\mathrm{m}}{ }^{\prime}\right]$ ) and quantum yield of photochemistry $\left(\mathrm{F}_{\mathrm{v}}{ }^{\prime} / \mathrm{F}_{\mathrm{m}}{ }^{\prime}\right)$.

Diurnal Survey. In July 2000, plant surveys were conducted to determine diurnal assimilation and observe differences, if any, between leaves of different age (as indicated by different nodes on the plant). Observations were made on six leaves from two plant heights $(0.15$ and $0.3 \mathrm{~m})$ and recorded at half hour increments over a 5 -h period. Start time was slightly after 1000 hours, and the final measurement occurred around 1500 hours.

Plant Response to Simulated Insect Herbivory. Once the daily photosynthesis pattern was determined, we measured assimilation of plants under simulated insect herbivory to characterize plant response. We assigned four levels of injury following a completely randomized design with six replications. Treatments were as follows: injured $1=$ one hole to the left of the midvein, injured $2=$ two holes (one on each side of the midvein), injured $4=$ four holes (two on each side of the midvein), and uninjured $=$ no holes punched in leaf tissue (control). We measured gas 
exchange parameters at three times: before injury, $1 \mathrm{~h}$ after injury, and $1 \mathrm{~d}$ after injury, beginning $1 \mathrm{~h}$ before solar noon on day 0 . The experimental unit was the measured plant; however, we measured only one leaf at a specific node where the treatment was applied. Treatments were applied to similar nodes on field plants of similar age determined by plant size and total number of leaves. Insect herbivory was simulated using a 4-mm cork borer and a rubber stopper at the leaf base, where insect feeding had previously been observed.

Using baseline information from the previous study, a follow-up study examined the effect of the greatest level of simulated insect herbivory (injured: four-hole treatment) on physiological response curves. This study was designed to measure physiological efficiency through assimilation response curves. For each set of response curves (light and $\mathrm{A} / \mathrm{C}_{\mathrm{i}}$ ), two treatments were applied following a completely randomized design with four replications. The experimental unit was the plant, although we measured only one leaf at a specific node where the treatment was applied. Treatments of injury were injured (four holes) and uninjured (control). Curves were generated $1 \mathrm{~h}$ after injury. Temperature, humidity, and $\mathrm{CO}_{2}$ concentration or light intensity remained constant as light intensity and $\mathrm{CO}_{2}$ values changed over time. Because the entire curve required $>20$ min depending on ambient conditions, leaves were injured over time to correspond to the $1 \mathrm{~h}$ postinjury measurement time.

Plant Response to Insect Herbivory. We conducted greenhouse trials to determine if insect herbivory induced similar plant responses as simulated insect herbivory. Again we measured physiological efficiency through $\mathrm{CO}_{2}$ response curves. We also added lightadapted fluorescence measures to examine photosystem response. For greenhouse experiments, A. subspicata plants of similar size $(\approx 0.3 \mathrm{~m} \mathrm{high})$ and of approximately equal number of nodes $(3-5)$ were transplanted from a circular grouping $(\approx 15$-m radius $)$ at Arbor Lake WMA to pots within a greenhouse. Plants had been growing at the marsh since germination that spring $(\sim 4$ mo earlier $)$. Soil conductivity at the transplant site measured $2592 \pm 60 \mu \mathrm{S}$ or the equivalent of $1.32 \pm 0.03$ ppt salinity. This was determined by reading conductivity of 10 subsamples of a known mass of soil well mixed in 1 liter distilled water with a salinity meter (YSI model 30; YSI, Yellow Springs, $\mathrm{OH}$ ). Transplants were grown in a 1:1 mixture of sterilized sand and silty-clay loam from the transplant source location, watered routinely with distilled water to simulate wetland drawdown hydrology, and maintained at $27 \pm 3^{\circ} \mathrm{C}$ under an ambient photoperiod (16:8 L:D with additional 400-W lighting).

To ensure experiments used homogenous sampling units, preliminary photosynthesis measurements were taken on 20 selected plants every hour over an afternoon interval from 1245 to 1545 hours. Because photosynthesis varied (from 9 to $27 \mu \mathrm{mol} \mathrm{CO}_{2} / \mathrm{m}^{2} / \mathrm{s}$ ), plants of similar rates were blocked in groups of three. After blocking, each plant in a block was assigned one of three treatments [caged-infested with two second- and third-instar Spilosoma virginica (Fabricius); a generalist Lepidoptera: Arctiidae; caged-uninfested, or uncaged-uninfested] following a randomized complete block design with six replications. All caged plants were covered in extra-fine mesh (2-mm openings) and sealed with tape. Plants were infested $1 \mathrm{~d}$ after survey calibration. We removed cages and measured plant response on remaining leaf tissue of the injured leaf after measurable injury occurred ( $2 \mathrm{~d}$ after infestation). Because larvae were small, injury occurred at a slower rate and in a manner akin to skeletonization rather than complete leaf tissue removal. All sampled units received the same treatment by machine and handling by investigator. Immediately after measurements of fluorometry and response curves, leaves were removed from the plant and frozen in liquid nitrogen for laboratory analyses.

We also examined $\mathrm{CO}_{2}$ response curves and fluorescence of field plants after the greenhouse experiment to determine if field plants responded the same to insect herbivory as greenhouse transplants did. Preliminary measurements on field plants were used to find leaves at equal nodes with similar photosynthetic rates. Treatments were applied to leaves of equal nodes (node 6 [10-12 total] from base, varying 0.6$0.8 \mathrm{~m}$ above ground) after a split plot. The main plot factor (uncaged uninfested) was applied to leaves at both nodes. The subplot factors were applied to leaves at the lower node following an unbalanced completely randomized design. Lower leaves at each node were assigned one of three treatments: caged-infested with one fifth- or sixth-instar S. virginica (four replications), caged-uninfested (four replications), or uncaged-uninfested (two replications). We applied the split plot to test whether sink-source relationships occurred when individual leaves were subjected to herbivory. All plants had no visible signs of injury or disease before applying treatments. Insects fed for $24 \mathrm{~h}$, and we removed cages and measured fluorometry and $\mathrm{CO}_{2}$ response curves of leaves at both nodes. Immediately after measures were recorded, leaves were removed from the plant and frozen in liquid nitrogen for laboratory analyses.

Enzyme Analyses. Plant samples collected on site in liquid nitrogen were stored in a $-20^{\circ} \mathrm{C}$ freezer. Samples were removed from the freezer, thawed, and prepared for protein analyses using a protocol from Heng-Moss et al. (2004) modified from Hildebrand et al. (1986). Soluble proteins were extracted by grinding plant tissues in a chilled mortar with $2-3 \mathrm{ml}$ (depending on sample mass) of $20 \mathrm{mM}$ HEPES buffer ( $\mathrm{pH} 7.2$ ), $1 \%$ polyvinylpyrrolidone, and a protease inhibitor cocktail $[0.3 \mathrm{~g} / 1 \mathrm{~g}$ of tissue, containing 4-(2-aminoethyl) benzenesullfonyl fluoride, bestatin, pepstatinA, E-64, leupeptin, and 1,10-phenanthroline; Sigma, St. Louis, MO]. The homogenate was centrifuged at $10,000 \mathrm{~g}$ for $10 \mathrm{~min}$ at $4^{\circ} \mathrm{C}$. The supernatant was collected and stored $(<4 \mathrm{~h})$ at $4^{\circ} \mathrm{C}$ until protein analyses.

After sample preparation, total protein content was determined using a bicinchoninic acid (BCA) protein assay (Pierce Chemical, Rockford, IL), with bovine serum albumin as its standard (Bradford 1976). 


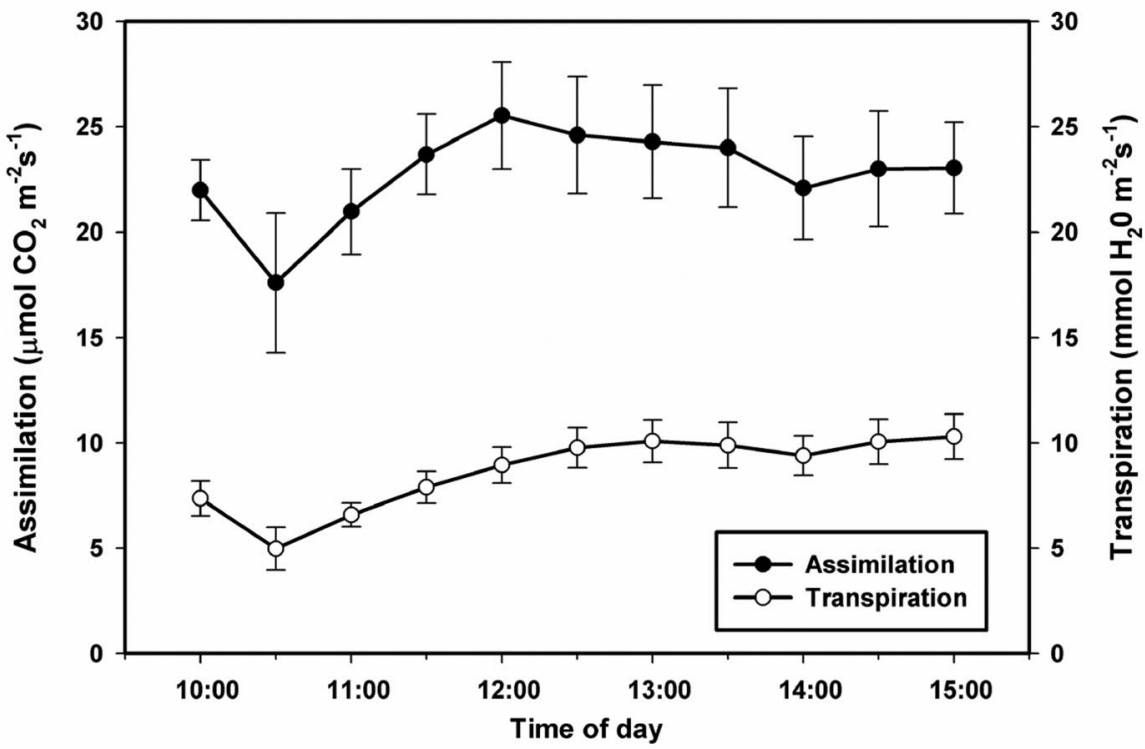

Fig. 1. Diurnal survey of mean $\pm \mathrm{SE}$ assimilation and leaf transpiration for A. subspicata.

Each aliquot of plant extract $(5 \mu \mathrm{l} \times 3$ replications $)$ was mixed with $75 \mu \mathrm{l}$ of $18 \mathrm{mM}$ guaiacol, $71.3 \mu \mathrm{l}$ of distilled water, and $25 \mu$ l HEPES ( $\mathrm{pH} 7.0$ ) in a microplate well. The enzyme reaction was started by adding $2.5 \mu \mathrm{l}$ of $30 \%$ hydrogen peroxide to each well and running the plate through a PowerWave microplate reader (Bio-Tek Instruments, Winooski, VT). After observing the increase in absorbance at $470 \mathrm{~nm}$ for $2 \mathrm{~min}$, we calculated peroxidase activity following a protocol from Heng-Moss et al. (2004) modified from Hildebrand et al. (1986).

To determine peroxidase isozyme and total protein profiles, native and denaturing sodium dodecyl sulfate (SDS) gels were run on a Criterion gel apparatus (Bio-Rad, Hercules, CA), using precast 12-well 10$20 \%$ polyacrylamide gels (Criterion gel; Bio-Rad). For native gels, a continuous buffer of Tris-glycine $(25 \mathrm{mM}$ Tris, $192 \mathrm{mM}$ glycine, $\mathrm{pH}$ 8.3) was used, whereas for SDS gels, a continuous buffer of Tris-glycine $(25 \mathrm{mM}$ Tris, 192 mM glycine, 1\% wt:vol SDS, pH 8.3) was used. Across all gels, equal amounts of protein, as determined by the BCA protein assay (Pierce Chemical), were diluted with a 1:1 gel loading buffer $(62.5 \mathrm{mM}$ Tris-HCl [pH 6.8], $40 \%$ glycerol, and $0.01 \%$ bromphenol blue for native gels and $62.5 \mathrm{mM}$ Tris- $\mathrm{HCl}$ [pH 6.8], 25\% glycerol, $0.01 \%$ bromphenol blue, $5 \%$ b-mercaptoethanol, and 2\% SDS for SDS gels) and loaded into wells. Native gels were electrophoresed until completion $(2-4 \mathrm{~h})$ at a lower voltage and temperature $\left(120 \mathrm{~V}\right.$ at $\left.4^{\circ} \mathrm{C}\right)$ than SDS gels $(190 \mathrm{~V}$ at room temperature). On completion of native gels, we visualized proteins by soaking gels in $50 \mathrm{mM}$ sodium acetate buffer (pH 5.0) for $5 \mathrm{~min}$. We added $0.01 \mathrm{~g}$ of 4-chloronaphthol (dissolved in $0.5 \mathrm{ml}$ methanol) and $20 \mu \mathrm{l}$ of $30 \%$ hydrogen peroxide to the soaking gel. Dark bands indicating zones of peroxidase activity appeared after $\approx 15$ min. Gels were fixed with $7 \%$ glacial acetic acid and photographed (Fluor-S MultiImager; Bio-Rad). After SDS gels completed electrophoresis, we visualized proteins by silver staining according to standardized protocols (Silver Stain; Bio-Rad).

Statistical Analyses. All raw data were analyzed using a mixed model analysis of variance (ANOVA; PROC MIXED; SAS Institute 2002) with means separated by least significant difference (LSD) test comparison where appropriate. All comparisons were made at the $P \leq 0.05$ level of significance. Photosynthesis response curves were fit and relevant parameters determined using the curve fitting software Photosyn Assistant (Dundee Scientific, Dundee, UK.)

\section{Results}

Gas Exchange and Fluorescence. The diurnal survey showed no differences between photosynthesis by leaf nodes within the range of nodes measured $(t=$ -0.082 , df $=32, P>0.4)$. Therefore, all measured leaves were used to characterize diurnal assimilation and transpiration (Fig. 1), and we used leaves of similar nodes in simulated insect and insect herbivory experiments.

In the second study evaluating plant response to levels of simulated insect herbivory, injured plants showed a reduction in gas exchange parameters (Table 1). One hour after simulated insect herbivory, $\mathrm{P}_{\mathrm{n}}, \mathrm{g}_{\mathrm{s}}, \mathrm{C}_{\mathrm{i}}$, and $\mathrm{E}$ decreased across all levels of injury $(P<0.05)$. Because leaf temperatures increased for all measure leaves $1 \mathrm{~h}$ after injury, vapor pressure deficits (based on leaf temperatures) differed between treatments $(P=0.01)$,. One day after injury, only plants under the greatest injury pressure (four-hole treatment) showed decreased $\mathrm{P}_{\mathrm{n}}(P=0.03)$; with increased VPD $(P=0.04)$, a differential in leaf blade 
Table 1. Results of repeated-measures ANOVA are shown for A. subspicata leaf gas exchange parameters for different injury treatments

\begin{tabular}{|c|c|c|c|c|c|c|c|c|c|c|c|}
\hline \multirow{2}{*}{$\begin{array}{l}\text { Source of } \\
\text { variation }\end{array}$} & \multirow{2}{*}{ df } & \multicolumn{2}{|c|}{$P_{n}$} & \multicolumn{2}{|r|}{$\mathrm{g}_{\mathrm{s}}$} & \multicolumn{2}{|c|}{$\mathrm{Ci}$} & \multicolumn{2}{|c|}{$\mathrm{E}$} & \multicolumn{2}{|c|}{ VPD } \\
\hline & & $F$-value & $P>F$ & $F$-value & $P>F$ & $F$-value & $P>F$ & $F$-value & $P>F$ & $F$-value & $P>F$ \\
\hline Injury type & 3,20 & 1.06 & 0.3860 & 2.15 & 0.1257 & 2.15 & 0.1255 & 1.12 & 0.3639 & 1.97 & 0.1508 \\
\hline Time & 2,40 & 22.23 & $<0.0001$ & 41.67 & $<0.0001$ & 20.91 & $<0.0001$ & 331.24 & $<0.0001$ & 169.56 & $<0.0001$ \\
\hline \multirow[t]{3}{*}{ Injury type $\times$ time } & 6,40 & 3.98 & 0.0088 & 2.91 & 0.0333 & 2.88 & 0.0342 & 1.99 & 0.1157 & 1.68 & 0.1790 \\
\hline & $n$ & $\mathbf{P}_{\mathbf{n}}$ & $g_{s}$ & $\mathrm{C}_{\mathrm{i}}$ & $\mathbf{E}$ & & VPD & & \multicolumn{3}{|c|}{ Environmental conditions ${ }^{a}$} \\
\hline & & & & & & & & & PAR & Temperature & RH \\
\hline Preinjury & & & & & & & & & 1,860 & $31.3 \pm 0.2^{\circ} \mathrm{C}$ & $41.2 \pm 0.7 \% \mathrm{a}$ \\
\hline Uninjured & 6 & $18.8 \pm 1.03 \mathrm{a}$ & $0.79 \pm 0.09 \mathrm{a}$ & $31.0 \pm 0.6 \mathrm{a}$ & $15.6 \pm 0.9 \mathrm{a}$ & & $2.48 \pm 0.2 \mathrm{a}$ & & & & \\
\hline Injured-1 $1^{b}$ & 6 & $20.2 \pm 1.99 a$ & $0.87 \pm 0.11 \mathrm{a}$ & $31.0 \pm 0.2 \mathrm{a}$ & $16.0 \pm 0.9 \mathrm{a}$ & & $2.39 \pm 0.2 \mathrm{a}$ & & & & \\
\hline Injured- $2^{c}$ & 6 & $18.9 \pm 1.07 \mathrm{a}$ & $0.88 \pm 0.09 \mathrm{a}$ & $31.6 \pm 0.4 \mathrm{a}$ & $16.2 \pm 0.5 \mathrm{a}$ & & $2.33 \pm 0.1 \mathrm{a}$ & & & & \\
\hline Injured-4 $4^{d}$ & 6 & $18.6 \pm 1.08 \mathrm{a}$ & $0.68 \pm 0.09 \mathrm{a}$ & $30.6 \pm 0.4 \mathrm{a}$ & $14.6 \pm 0.9 \mathrm{a}$ & & $2.58 \pm 0.1 \mathrm{a}$ & & & & \\
\hline $1 \mathrm{~h}$ after injury & & & & & & & & & 2,160 & $32.8 \pm 0.2^{\circ} \mathrm{C}$ & $57.5 \pm 1.8 \% \mathrm{~b}$ \\
\hline Uninjured & 6 & $18.2 \pm 1.01 \mathrm{a}$ & $0.67 \pm 0.08 \mathrm{a}$ & $31.1 \pm 0.7 \mathrm{a}$ & $10.3 \pm 1.0 \mathrm{~b}$ & & $1.84 \pm 0.1 b$ & & & & \\
\hline Injured- $1^{b}$ & 6 & $15.4 \pm 2.10 \mathrm{~b}$ & $0.39 \pm 0.08 b$ & $29.1 \pm 0.7 b$ & $7.6 \pm 1.0 \mathrm{~b}$ & & $2.39 \pm 0.3 a$ & & & & \\
\hline Injured- $2^{c}$ & 6 & $14.6 \pm 1.30 \mathrm{~b}$ & $0.32 \pm 0.06 \mathrm{~b}$ & $28.2 \pm 0.8 b$ & $7.2 \pm 1.1 \mathrm{c}$ & & $2.42 \pm 0.1 \mathrm{a}$ & & & & \\
\hline Injured- $-4^{d}$ & 6 & $13.9 \pm 1.49 \mathrm{~b}$ & $0.28 \pm 0.05 \mathrm{~b}$ & $27.8 \pm 0.4 \mathrm{~b}$ & $7.0 \pm 1.2 \mathrm{c}$ & & $2.60 \pm 0.1 \mathrm{a}$ & & & & \\
\hline $1 \mathrm{~d}$ after injury & & & & & & & & & 1,988 & $31.6 \pm 0.1^{\circ} \mathrm{C}$ & $71.2 \pm 1.4 \% \mathrm{c}$ \\
\hline Uninjured & 6 & $19.5 \pm 1.04 \mathrm{a}$ & $0.70 \pm 0.06 \mathrm{a}$ & $31.4 \pm 0.3 \mathrm{a}$ & $8.2 \pm 0.6 b$ & & $1.37 \pm 0.05 \mathrm{c}$ & & & & \\
\hline Injured-1 $1^{b}$ & 6 & $18.9 \pm 2.07 \mathrm{a}$ & $0.76 \pm 0.12 \mathrm{a}$ & $31.8 \pm 0.2 \mathrm{a}$ & $8.3 \pm 0.7 \mathrm{~b}$ & & $1.42 \pm 0.13 c$ & & & & \\
\hline Injured-2 $2^{c}$ & 6 & $17.8 \pm 1.07 \mathrm{a}$ & $0.65 \pm 0.10 \mathrm{a}$ & $31.4 \pm 0.5 \mathrm{a}$ & $7.8 \pm 0.6 \mathrm{bc}$ & & $1.46 \pm 0.11 \mathrm{c}$ & & & & \\
\hline Injured- $4^{d}$ & 6 & $14.6 \pm 1.60 \mathrm{~b}$ & $0.46 \pm 0.09 \mathrm{a}$ & $30.5 \pm 1.1 \mathrm{a}$ & $6.7 \pm 0.9 \mathrm{bc}$ & & $1.72 \pm 0.12 \mathrm{~d}$ & & & & \\
\hline
\end{tabular}

Mean \pm SE are shown before (preinjury) and after ( $1 \mathrm{~h}$ and $1 \mathrm{~d}$ after injury) mechanical injury treatments were applied. Gas exchange parameters reflect photosynthesis: $\mathrm{P}_{\mathrm{n}}\left(\mu \mathrm{mol} \mathrm{CO} \mathrm{CO}_{2} / \mathrm{m}^{2} / \mathrm{s}\right)$, conductance: $\mathrm{g}_{\mathrm{s}}\left(\mathrm{mol} \mathrm{H}_{2} \mathrm{O} / \mathrm{m}^{2} / \mathrm{s}\right)$, intercellular $\mathrm{CO}_{2}: \mathrm{C}_{\mathrm{i}}(\mathrm{Pa})$, transpiration: $\mathrm{E}(\mu \mathrm{g}$ $\mathrm{H}_{2} \mathrm{O} / \mathrm{m}^{2} / \mathrm{s}$ ), and vapor pressure deficit ( $\mathrm{VPD} ; \mathrm{kPa}$ ) based on leaf temperature. Environmental conditions reflect ambient light intensity (PAR), leaf temperatures, and sample cell relative humidity.

Treatments followed by same letters are not significantly different from each other based on test of LSD, $P>0.05$.

${ }^{a}$ Averaged values for all treatments.

${ }^{b}$ Injury was one 4 -mm hole punched into the leaf tissue left of the midvein.

${ }^{c}$ Injury was two 4 -mm holes punched into the leaf tissue, one on either side of the midvein.

${ }^{d}$ Injury was four 4 -mm holes punched into the leaf tissue, two on either side of the midvein.

temperature was present. All other levels of injury showed no differences compared with uninjured plants $1 \mathrm{~d}$ after injury (Table 1 ). Light and $\mathrm{CO}_{2}$ response curves were generated from plants with the highest level of injury. These response curves showed decreased maximal assimilation and carboxylation efficiency (Figs. 2 and 3). Although response curves show averaged response data, individual response curves were used for all analyses. For light curves, assimilation differed at light levels $>300$ PAR with corresponding significance in conductance and transpiration at $>200$ PAR for injured versus uninjured plants $(P<0.05)$. Quantum efficiency or the slope along the linear portion of the response curve (from regression analysis: slope injured $=0.022 \pm 0.002$, slope uninjured $=0.018 \pm 0.005)$ did not differ between injured and uninjured plants $(P>0.1)$. Although photosynthetic rates seem low, curves were generated under similar albeit stressful environmental conditions for a $\mathrm{C}_{3}$ plant $\left(40^{\circ} \mathrm{C}, 16.4 \% \mathrm{RH}\right)$, and interpretations must be considered under their environmental context (von Caemmerer 2000). For $\mathrm{CO}_{2}$ response curves, assimilation differed only at high external levels of $\mathrm{CO}_{2}\left(\mathrm{C}_{\mathrm{a}}=81.1,101.4 \mathrm{~Pa}\right.$; Fig. 3). The carboxylation efficiency or slope of the $\mathrm{CO}_{2}$ response curves calculated over the linear portion $\left(\mathrm{C}_{\mathrm{i}}\right.$ through ambient $\mathrm{C}_{\mathrm{a}}$ or $<40.6 \mathrm{~Pa}$ ) by regression analysis did not differ between injured and uninjured plants $(P=$ $0.37,0.16$, respectively). Calculations of stomatal limitation showed no effect of treatment. From $A / C_{i}$ curves, leaf respiration, light saturated maximum electron transport rate $\left(\mathrm{J}_{\max }\right)$, and maximum carboxylation rate by Rubisco $\left(\mathrm{V}_{\mathrm{cmax}}\right)$ decreased under simulated insect injury (Table 2 ).

In the third study, we evaluated insect herbivore injury in the greenhouse and in the field. Injured plants responded with decreased gas exchange parameters. After insect feeding, infested plants showed much lower $\mathrm{P}_{\mathrm{n}}$ and $\mathrm{E}$ relative to uninfested plants; however, $\mathrm{g}_{\mathrm{s}}$ did not differ, whereas $\mathrm{C}_{\mathrm{i}}$ increased $(P<$ 0.05; Table 3). Assimilation rates differed between treatments at $\mathrm{CO}_{2}$ levels $>20.3 \mathrm{~Pa}$ for response curves (Fig. 4). Injured plants also showed increased $\mathrm{C}_{\mathrm{i}}$ compared with uninjured plants $(P<0.05)$, although there were no differences in other gas exchange parameters. Carboxylation efficiency differed between treatments $(P<0.0001)$. Calculations of stomatal limitations showed no insect induced stomatal limitations. Infested plants had lower respiration, maximum rubisco carboxylation rate $\left(\mathrm{V}_{\mathrm{cmax}}\right)$, and PAR-saturated electron transport rate $\left(\mathrm{J}_{\max }\right)$ in the greenhouse experiment (Table 2).

In field experiments, assimilation rates and other gas exchange parameters were similar among treatments. $\mathrm{CO}_{2}$ response curves showed all plants to be environmentally stressed and unable to plateau in response to elevated levels of $\mathrm{CO}_{2}$ (Fig. 5). Calculations of stomatal limitations and carboxylation efficiency showed no differences. 


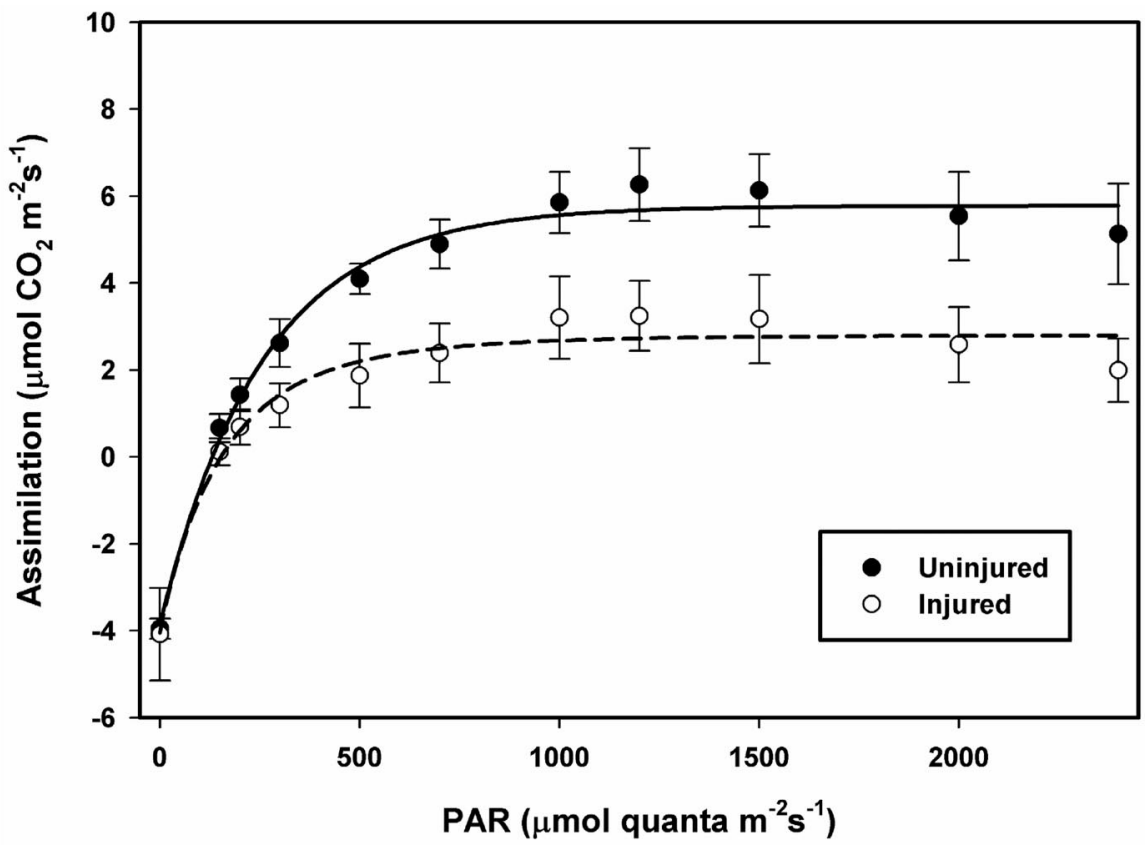

Fig. 2. Light response curves of mechanically injured A. subspicata leaves showing mean \pm SE assimilation rates for injured (I) and uninjured (U) leaves. Light compensation point (PAR@x-intercept) U = $117 \pm 14$; I = 153 \pm 46 . Maximal assimilation rate $\mathrm{U}=10.46 \pm 1.30 ; \mathrm{I}=6.79 \pm 1.76$. Low photosynthetic rates resulted from stressful ambient conditions for a $\mathrm{C}_{3}$ plant $\left(40^{\circ} \mathrm{C}, 16.4 \% \mathrm{RH}\right)$.

Fluorescence measurements indicated no significant differences between treatments for all parameters examined $(P>0.05)$. Quantum yield of photo- chemistry $\mathrm{F}_{\mathrm{v}}{ }^{\prime} / \mathrm{F}_{\mathrm{m}}$ ' were highest in infested plants (caged-infested $=0.22 \pm 0.03$, caged-uninfested $=$ $0.21 \pm 0.02$, uncaged-uninfested $=0.18 \pm 0.03)$.

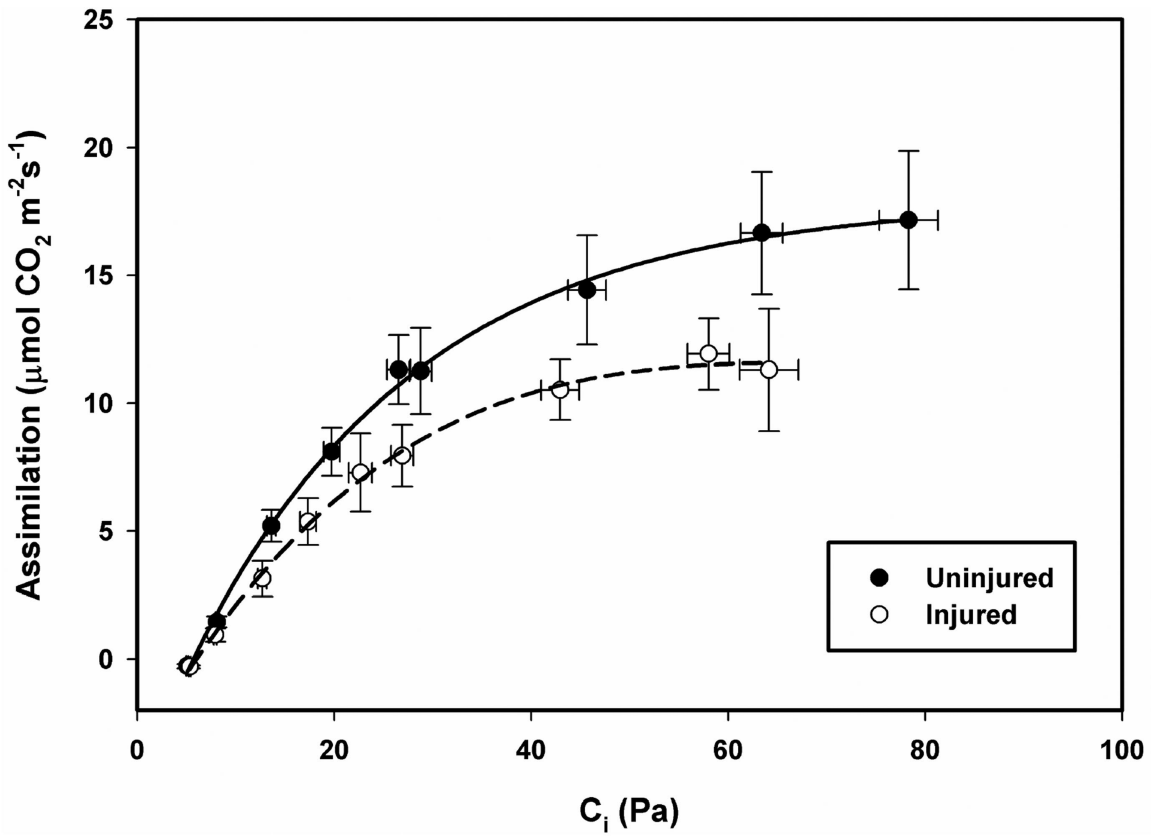

Fig. 3. $A / C_{i}$ response curves of mechanically injured A. subspicata leaves showing mean $\pm \mathrm{SE}$ assimilation rates for injured (I) and uninjured (U) leaves. $\mathrm{CO}_{2}$ compensation point (x-intercept) $\mathrm{U}=5.8 \pm 0.1 \mathrm{~Pa} ; \mathrm{I}=6.2 \pm 0.3 \mathrm{~Pa}$. Photosynthetic rates were measured under tolerable ambient conditions $\left(27^{\circ} \mathrm{C}, 45.8 \% \mathrm{RH}\right)$. 


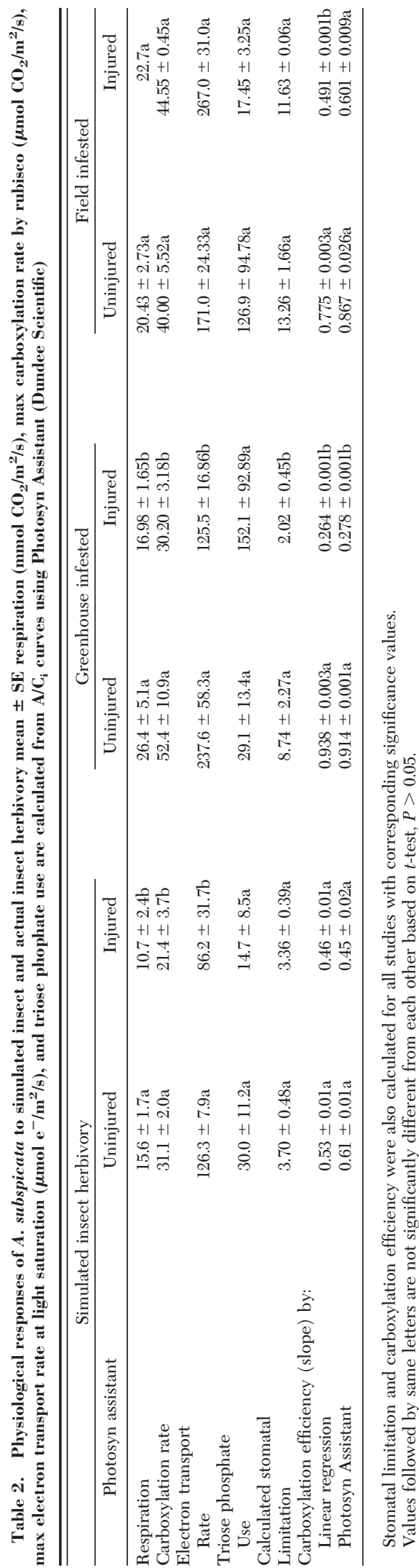

Enzyme Activity and Native Gels. Leaves from studies using insect injured plants were analyzed for differences in peroxidase profiles and activity. Because of the blocked arrangement, we compared peroxidase activity using photosynthesis as a covariate (greenhouse: $\mathrm{df}=5,53 ; F=3.56 ; P=0.0081$; field: $\mathrm{df}=9,47$; $F=4.6 ; P=0.0004)$. Greenhouse plants showed elevated enzyme activity in caged-infested compared with caged uninfested leaves ( $18.9 \pm 2.0$ and $16.3 \pm 1.1$ $\mu \mathrm{mol} / \mathrm{min} / \mathrm{mg}$, respectively; LSD test, $P=0.005$ ). In field studies, infested plants also showed a trend for elevated levels of enzyme activity. Caged-uninfested leaves had lower specific activity than infested leaves $(11.9 \pm 2.3$ and $19.6 \pm 4.7 \mu \mathrm{mol} / \mathrm{min} / \mathrm{mg}$, respectively), although significant differences were difficult to detect because of the small sample size $(n=3)$. For both field and greenhouse experiments, total protein content did not differ between treatments. Infested plants tended to have lower total protein content than uninfested plants in the greenhouse $(34.0 \pm 2.2$ and $39.8 \pm 2.2 \mu \mathrm{g} / \mathrm{g}$ plant material, respectively) and higher total protein than uninfested plants in the field $(85.1 \pm 3.4$ and $72.6 \pm 4.2 \mu \mathrm{g} / \mathrm{g}$ plant material, respectively). Overall, field plants showed higher protein content than greenhouse plants.

Native gel electrophoresis of greenhouse plants showed darker banding patterns in three of six infested treatments (Fig. 6). The presence of darker bands confirmed the increased activity observed under insect herbivory. Field plants, however, showed no trends in enzyme banding patterns. Also, SDS gels showed no trends between infested and uninfested plants of both field and greenhouse studies.

\section{Discussion}

In these experiments, A. subspicata had reduced assimilation after herbivore injury. Studies investigating herbivory in other plant systems showed variable physiological effects depending on the insect, its manner of feeding, and the plant system being fed on. Peterson et al. (1998) showed that feeding by Mexican bean beetle (Epilachna varivestis Mulsant) on soybean (Glycine max L. Merrill) and dry bean (Phaseolus vulgaris $\mathrm{L}$.) decreased maximal assimilation $\left(\mathrm{A}_{\max }\right)$ under high light. Injured plants also showed decreased assimilation immediately after injury and throughout the remaining study time $(31 \mathrm{~d})$. Our data showed an initial decrease in $\mathbf{A}_{\max }$ under simulated insect herbivory. We also saw decreased assimilation under infestation by S. virginica when $<40 \%$ of the leaf area was defoliated. Although feeding injury by E. varivestis is classified as leaf skeletonization, early-instar S. virginica removed surface foliar material similarly, leaving a thin membrane of connective tissue behind. Later instars, however, completely removed all tissue fed on. Similarly, a study that used first- and fourth-instar cabbage loopers, Trichoplusia ni (Hübner), showed the earlier instars reduced photosynthetic efficiency more than the later instars over time (Tang et al. 2006). Thus, the reduction in assimilation may be tied to the physical feeding mechanism. 


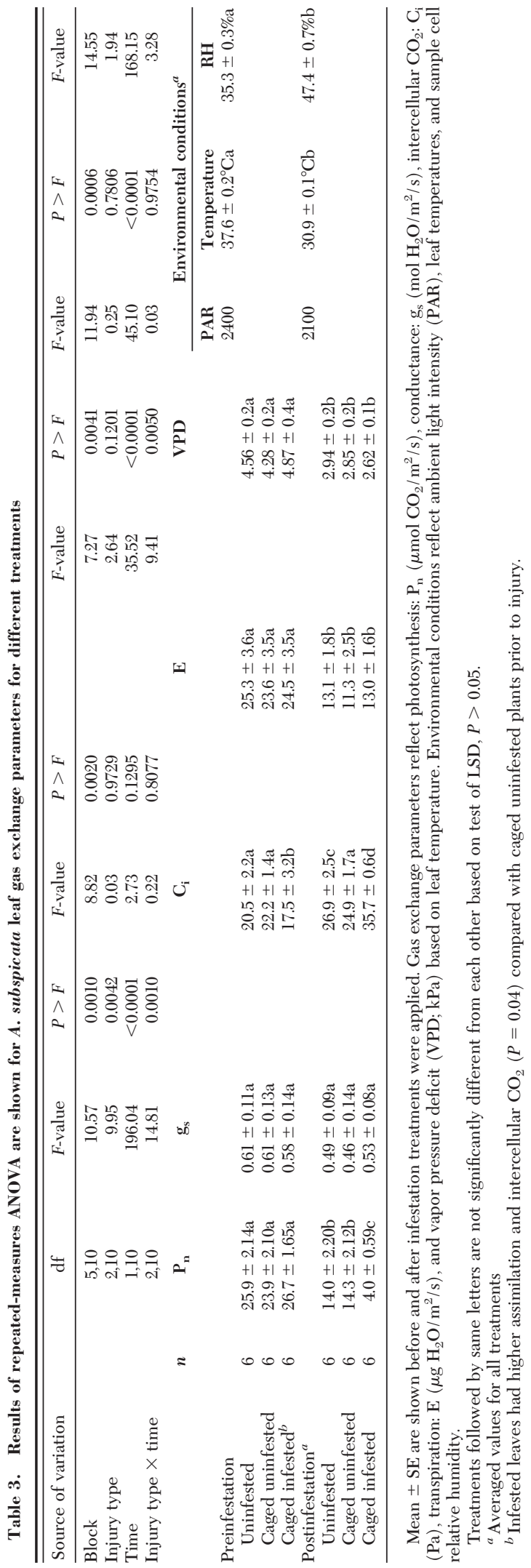




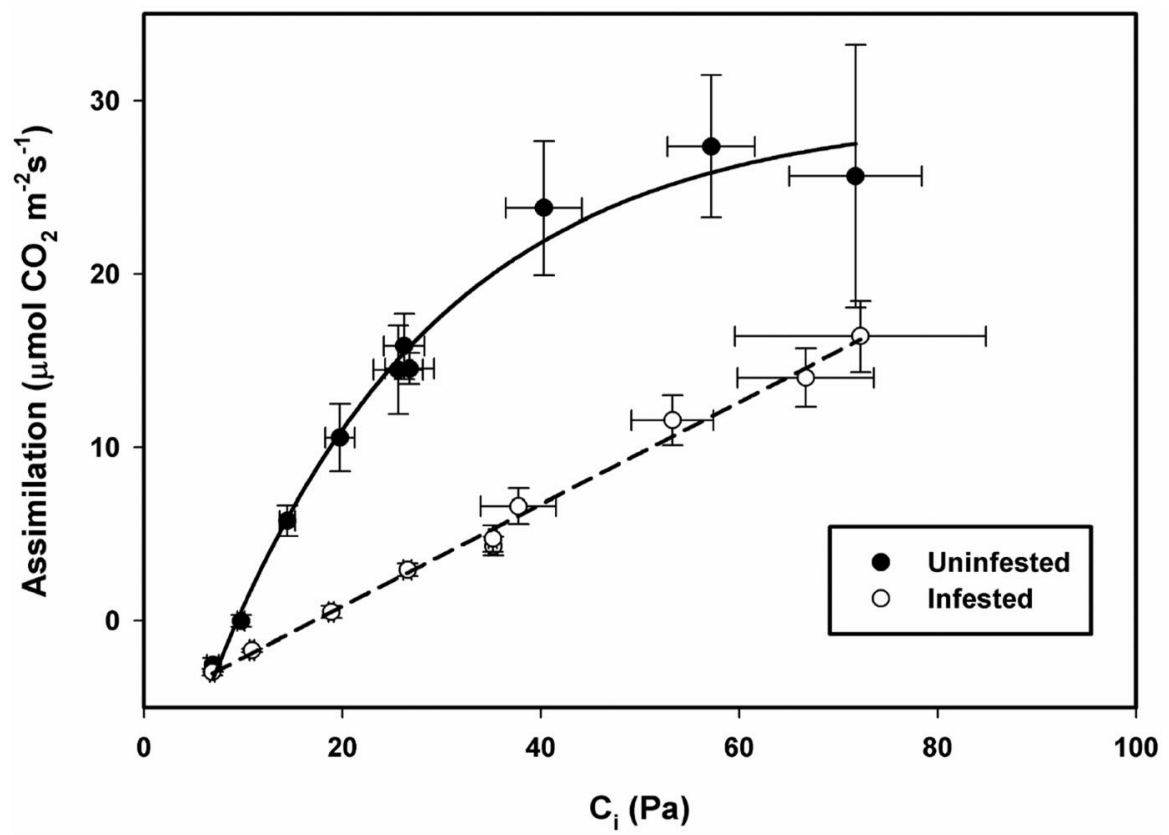

Fig. 4. $\quad \mathrm{A} / \mathrm{C}_{\mathrm{i}}$ response curves of greenhouse-infested A. subspicata leaves $2 \mathrm{~d}$ after injury showing mean $\pm \mathrm{SE}$ assimilation rates for infested $(\mathrm{I})$ and uninfested $(\mathrm{U})$ leaves. $\mathrm{CO}_{2}$ compensation point (x-intercept) $\mathrm{U}=4.6 \pm 0.6 \mathrm{~Pa} ; \mathrm{I}=16.8 \pm 0.8 \mathrm{~Pa}$. Photosynthetic rates were measured under tolerable ambient conditions $\left(31^{\circ} \mathrm{C}, 47.4 \% \mathrm{RH}\right)$.

In previous studies, investigators have observed that both simulated insect and insect herbivory (mass tissue removal) had no effect on plant gas exchange and
$\mathrm{CO}_{2}$ response curves (Peterson et al. 1992, Hunt et al 2003, Peterson et al. 2004). In contrast, other studies have shown a breakdown in assimilation or photosyn-

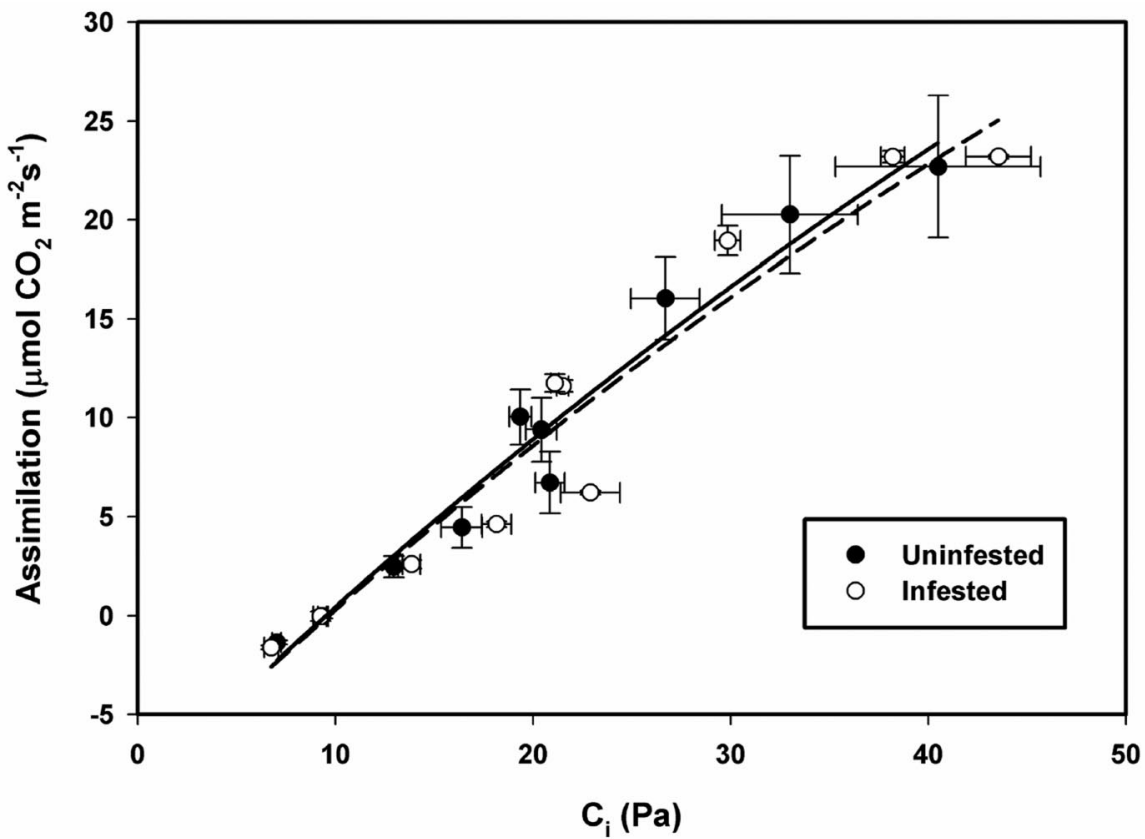

Fig. 5. A/ $\mathrm{C}_{\mathrm{i}}$ response curves of field-infested A. subspicata leaves $1 \mathrm{~d}$ after injury showing mean $\pm \mathrm{SE}$ assimilation rates for infested (I) and uninfested (U). $\mathrm{CO}_{2}$ compensation point (x-intercept) $\mathrm{U}=9.6 \pm 0.5 \mathrm{~Pa} ; \mathrm{I}=9.6 \pm 0.5 \mathrm{~Pa}$. Photosynthetic rates were measured under slightly stressful ambient conditions $\left(35.2^{\circ} \mathrm{C}, 36.7 \% \mathrm{RH}\right)$. 


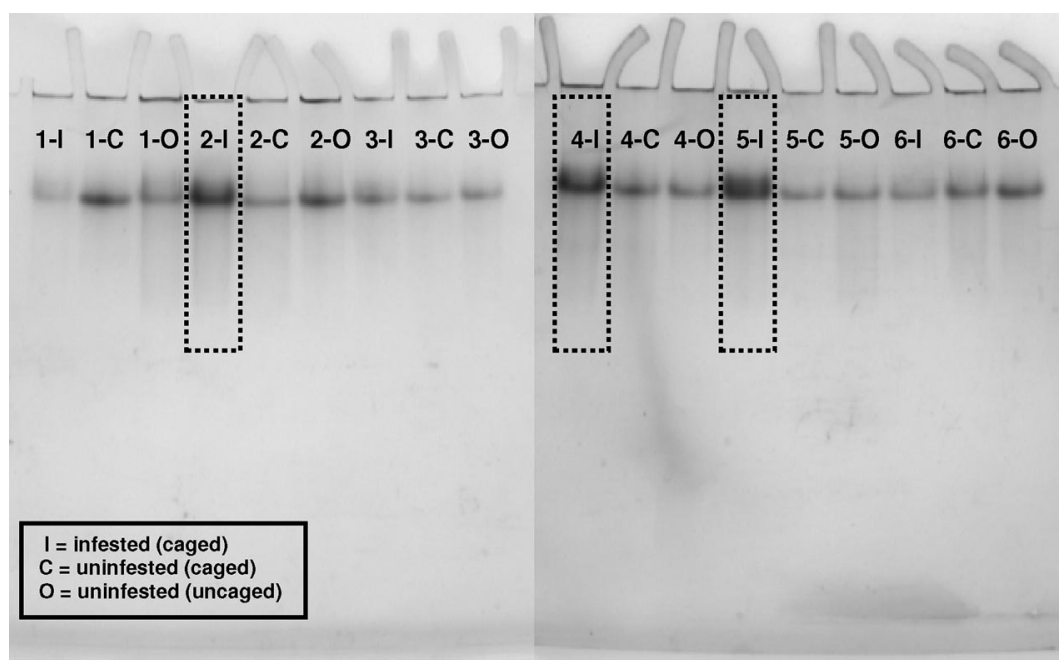

Fig. 6. Native gels stained for peroxidase activity in greenhouse A. subspicata leaves. Darker bands indicate increased peroxidase activity. Gel orientation is scalar with block (number) followed by treatment (letter). Equal amounts of protein $(110 \mu \mathrm{g})$ were loaded per well.

thetic efficiency in remaining uninjured leaf tissue (Zangerl et al. 2002, Aldea et al. 2005, Delaney and Higley 2006, Tang et al. 2006). Our data also showed mass tissue removal reduced $\mathrm{P}_{\mathrm{n}}$ in remaining leaf tissue as shown by differences in $\mathrm{CO}_{2}$ response curves $1 \mathrm{~h}$ after mechanical injury and $2 \mathrm{~d}$ after insect feeding. Following the interpretations of Farquhar and Sharkey (1982) and Sharkey (1985) of photosynthesis, linear portions of $\mathrm{CO}_{2}$ response curves represent the amount of rubisco activity within the leaf. On saturation (flattening of the curve), rubisco is no longer the limiting reagent as ATP regeneration and electron transport limit assimilation. Our data suggested rubsico activity differed between treatments as indicated by differences in slopes. Differences in the saturated portion of the $\mathrm{CO}_{2}$ curves may be caused by reduced electron transport (Figs. 3 and 4). We also saw increased $\mathrm{C}_{\mathrm{i}}$ in infested plants compared with uninfested plants in the greenhouse, which suggests $\mathrm{CO}_{2}$ is diffusing across stomata or insect induced apertures in leaf tissue but not being consumed by carbon fixing reactions. Therefore, mesophyll limitations may be limiting photosynthesis. Furthermore, injured plants already under rubisco limitation may also decrease assimilation through down-regulation or other processes not related to electron transport. Thus, it seems initial rubisco limitation alters the ability of $A$. subspicata to compensate for insect injury.

Time-course surveys showed plants became desensitized to increasing levels of injury and most eventually compensated for injury. One hour after injury, photosynthetic rates decreased with increasing degrees of injury (Table 1). Rate reduction approached a maximal decrease, suggesting additional injury (tissue removal) would not alter plant response much more than the reduction observed at the 4-hole treatment. The maximal leaf defoliation under simulated insect herbivory removed $<25 \%$ of the available leaf tissue with lesser injury (one- and two-hole), representing $10-20 \%$ leaf defoliation. However, by $1 \mathrm{~d}$ after injury, rates of all but the most injured plants recovered, indicating transient rate reduction and plant compensation. This transient reduction in assimilation accompanied decreased $\mathrm{C}_{\mathrm{i}}$ and transpiration. If both internal $\mathrm{CO}_{2}$ and transpiration decrease, this action suggests stomatal closure is occurring restricting the evaporation of water and intake of $\mathrm{CO}_{2}$, ultimately decreasing photosynthesis. Our initial decrease in stomatal conductance confirmed this ( $1 \mathrm{~h}$ after injury). One day after simulated insect herbivory, $\mathrm{C}_{\mathrm{i}}$ increased but conductance showed no difference. Thus, the observed transient stomatal limitation is a reaction to rapid water loss causing stomata to close. However, calculations of stomatal limitations showed no treatment effects. Thus, gas exchange indicates stomatal limitations should be reviewed in the context of time and environments. Further analysis showed rate reduction not to be associated with stomata. Furthermore, increased intercellular $\mathrm{CO}_{2}$ with prolonged injury (greenhouse data) suggests $C_{i}$ is not being used as efficiently as in uninjured plants. This reduced efficiency, likely a result of disrupted rubisco activity, implies mesophyll limitations are responsible for reduced assimilation. The strong difference between infested and uninfested plants in the greenhouse experiment is most likely a result of more prolonged feeding (2 d) and an environmental interaction that affected assimilation across all treatments (Table 2). In this situation, infested plants were almost entirely limited by rubisco activity as the plants almost did not attain photosynthetic saturation.

Light assimilation curves also indicated rubisco limitations. Lauerer et al. (1993) showed reduction in levels of rubisco resulted in reduced rate potential $\left(A_{\max }\right)$. Our data showed rate reduction under injury although response curves held similar slopes along 
the linear portion (PAR $<400)$. With no observed differences in the linear portion, light activation of rubisco occurred similarly across treatments. On saturation, however, light no longer limited assimilation, and the observed reduction in assimilation is suggestive of decreased carboxylation efficiency or reduced levels of rubisco. Light adapted measures of fluorometry $\left(\mathrm{F}_{\mathrm{v}}\right.$ ' $/ \mathrm{F}_{\mathrm{m}}$ '; defined by van Kooten and Snel 1990) showed no difference in the relative measures of the number of reaction centers involved in photosynthesis (the effective quantum yield of photochemistry). These results are similar to findings by Haile and Higley (2003), where arthropod feeding did not alter photosystem efficiency in plants. Similar findings in Aldea et al. (2005) and Tang et al. (2006) showed overall efficiency of photosystem II was not diminished under insect defoliation injury, despite diminutive effects in photosynthetically depressed tissues (close proximity to site of injury). Therefore, we can assume herbivory on A. subspicata does not inhibit the total leaf or overall light reactions of photosynthesis. Subsequently, any decline in assimilation must result from nonphotosystem limitations (stomatal or mesophyll limitations).

In other evaluations of plant-insect interactions, some of the initial responses of plants to injury included changes in oxidative enzyme levels (Felton et al. 1994, Ni et al. 2001, Heng-Moss et al. 2004). One specific oxidative enzyme, peroxidase, has been shown to increase when plants encounter insect related stress (Felton et al. 1994, Ni et al. 2001, Ni and Quisenberry 2003, Heng-Moss et al. 2004,zharvx) and has also been linked directly to salt tolerance in other Atriplex species (Wang et al. 1997). Felton et al. (1994) found herbivore defoliation increased selective oxidative enzymes, and several mechanical defoliation studies since then have shown plants to respond specifically with increased peroxidase activity when introduced to injury (Tscharntke et al. 2001, Kruzmane et al. 2002, Roitto et al. 2003). Increased activity would indicate potentially harmful oxidative species created by stress are being reduced to prevent further tissue injury. In greenhouse and field experiments, enzyme analyses showed increased peroxidase activity within infested treatments. Our data may provide some perspective for future studies evaluating salt tolerant species and their physiological response to herbivory. Also, there seems to be a need to characterize mechanisms for tolerance such as up-regulation of oxidative enzymes (peroxidase) in halophytic species.

Halophytes tend to have an advantage over generalist arthropod herbivores indirectly by osmoregulating and storing salts in foliage (Ungar 1998). Generalists may be deterred by this accumulation; however, if they tolerate those salts, plant energy efficiency becomes jeopardized having already expended energy on mechanisms in defense of the environment. The energetic tradeoff associated with maintaining osmotic balance in the presence of stored salts may be compromised as foliar material is removed exposing the plant to losses in water and energy with decreased photosynthesis efficiency. While this study documented the impact of the generalist feeder, S. virginica, on gas exchange responses of A. subspicata, comparisons between guilds of herbivores and specialist herbivores would provide additional insights into how these salt-adapted plants respond to insect injury.

Atriplex plants live amid stressful environmental conditions yet have adapted tolerance to abiotic factors. Presence of insect herbivore stress can create conditions where stress tolerance may be decreased. This has direct practical application to this genus where studies into biotic stress are limited and physiological examinations of plant response do not exist. As plants within the Atriplex genus have also been selected as sources for gene transfer to regulate salt tolerance (Ohta et al. 2002, Shen et al. 2002), understanding the relationship between salt tolerance and insect herbivory is essential. If salt tolerance comes at the cost of susceptibility to biotic interference, transgenics may be at risk for heightened response to insect herbivory. Future studies should evaluate the efficacy of transgenic salt tolerance within the context of herbivory.

\section{Acknowledgments}

We thank S. M. Louda and S. M. Spomer for constructive discussions and editorial remarks, L. D. Franzen and S. E. Svehla for assistance with field experiments, and T. E. Eickhoff and S. Adams for greenhouse maintenance. We also thank the Nebraska Game and Parks Commission and Lancaster County Department of Parks and Recreation for granting us access to property. This work was supported by the Nebraska Agricultural Experiment Station (Projects NEB17-078 and NEB-17-080) and by awards to P.D.N. from the University of Nebraska Pepsi Endowment and Program of Excellence Funds for Undergraduate and Creative Activities and Research Experiences. This is paper 15100 of the journal series of the University of Nebraska Agricultural Research Division.

\section{References Cited}

Aldea, M., J. G. Hamilton, J. P. Resti, A. R. Zangerl, M. R. Berenbaum, and E. H. DeLucia. 2005. Indirect effects of insect herbivory on leaf gas exchange in soybean. Plant Cell Environ. 28: 402-411.

Allison, S. D., and J. C. Shultz. 2004. Differential activity of peroxidase isoenzymes in response to wounding, gypsy moth, and plant hormones in northern red oak (Quercus rubra L.). J. Chem. Ecology 30: 1263-1379.

Bradford, M. M. 1976. A rapid and sensitive method for the quantification of microgram quantities of protein utilizing the principle of protein-dye binding. Anal. Biochem. 72: 248-254.

Cibils, A. F., D. M. Swift, and E. D. McArthur. 1998. Plantherbivore interactions in Atriplex: current state of knowledge. USDA Forest Service General Technical Report RMRS-GTR-14.

Delaney, K.J.D., and L. G. Higley. 2006. An insect countermeasure impacts plant physiology: midrib vein cutting, defoliation and leaf photosynthesis. Plant Cell Environ. 29: 1245-1258.

Farquhar, G. D., and T. D. Sharkey. 1982. Stomatal conductance and photosynthesis. Annu. Rev. Plant Physiol. 33: 317-345. 
Farrar, J., and R. A. Gersib. 1991. Nebraska salt marshes: last of the least. Nebraskaland 69: 18-41.

Felton, G. W., C. B. Summers, and A. J. Mueller. 1994. Oxidative responses in soybean foliage to herbivory by bean leaf beetle and three-corned alfalfa leaf hopper. J. Chem. Ecology 20: 639-650.

Flowers, T. J., P. F. Troke, and A. R. Yeo. 1977. The mechanism of salt tolerance in halophytes. Annu. Rev. Plant Physiol. 28: 89-121.

Glenn, E. P., and J. J. Brown. 1998. Effects of soil salt levels on the growth and water use efficiency of Atriplex canescens (Chenopodiaceae) varieties in drying soil. Am. J. Botany. 85: 10-16.

Haile, F. J., and L. G. Higley. 2003. Changes in soybean gas-exchange after moisture stress and spider mite injury. Environ. Entomol. 32: 433-440.

Heng-Moss, T., G. Sarath, F. Baxendale, D. Novak, S. Bose, X. Ni, and S. Quissenberry. 2004. Characterization of oxidative enzyme changes in buffalograsses challenged by Blissus occiduus. J. Econ. Entomol. 97: 1086-1095.

Hildebrand, D. F., J. G. Rodriguez, G. C. Brown, K. T. Luu, and C. S. Volden. 1986. Peroxidative responses of leaves in two soybean genotypes injured by twospotted spider mites (Acari: Tetranychidae). J. Econ. Entomol. 79: 1459 1465 .

Hunt, T. E., L. G. Higley, and F. J. Haile. 2003. Imported longhorned weevil (Coleoptera: Curculionidae) injury to soybean: physiological response and injury guild-level economic injury levels. J. Econ. Entomol. 96: 1168-1173.

Kruzmane, D., L. Jankevica, and G. Ievinsh. 2002. Effect of regurgitant from Leptinotarsa decemlineata Say on wound responses in Solanum tuberosum L. and Phaseolus vulgaris L. Physiol. Plant. 115: 577-584.

Lauerer, M., D. Saftic, W. P. Quick, C. Labate, K. Fichtner, E. D. Schulze, S. R. Rodermel, L. Bogorad, and M. Stitt. 1993. Decreased ribulose-1,5-biphosphate carboxylaseoxygenase in transgenic tobacco transformed with 'antisense' rbcS. Planta 190: 332-345.

Ni, X., and S. Quisenberry. 2003. Possible roles of esterase glutathione S-transferase, and superoxide dismutase activities in understanding aphid-cereal interactions. Entomol. Exp. Appl. 108: 187-195.

Ni, X., S. Quisenberry, T. Heng-Moss, J. Markwell, G. Sarath, R. Klucas, and F. Baxendale. 2001. Oxidative responses of resistant and susceptible cereal leaves to symptomatic and nonsymptomatic cereal aphid (Hempitera: Aphididae) feeding. J. Econ. Entomol. 94: 743-751.

Noe, G. B., and J. B. Zedler. 2000. Differential effects of four abiotic factors on the germination of salt marsh annuals. Am. J. Botany. 87: 1679-1692.

Noe, G. B., and J. B. Zedler. 2001. Spatio-temporal variation of salt marsh seedling establishment in relation to the abiotic and biotic environment. J. Veg. Sci. 12: 61-74.

Ohta, M., Y. Hayashi, A. Nakashima, A. Hamada, A. Tanaka, T. Nakamura, and T. Hayakawa. 2002. Introduction of a $\mathrm{Na}^{+} / \mathrm{H}^{+}$antiporter gene from Atriplex gmelini confers salt tolerance to rice. FEBS Lett. 532: 279-282.

Osmond, C. B., O. Bjorkman, and D. J. Anderson (eds) . 1980. Physiological processes in plant ecology: toward a synthesis with Atriplex. Springer-Verlag, Berlin, Germany.

Pearcy, R., and S. Ustin. 1984. Effects of salinity on growth and photosynthesis of three California tidal marsh species. Oecologia (Berl.) 62: 68-73.

Peterson, R.K.D., S. D. Danielson, and L. G. Higley. 1992 Photosynthetic responses of alfalfa to actual and simulated alfalfa weevil (Coleoptera: Curculionidae) injury. Environ. Entomol. 21: 501-507.
Peterson, R.K.D., L. G. Higley, F. J. Haile, and J.A.F. Barrigossi. 1998. Mexican bean beetle (Coleoptera: Coccinelidae) injury affects photosynthesis of Glycine max and Phaseolus vulgaris. Environ. Entomol. 27: 373-381.

Peterson, R.K.D., C. L. Shannon, and A. W. Lenssen. 2004. Photosynthetic response of legume species to leaf-mass consumption injury. Environ. Entomol. 33: 450-456.

Plaut, Z., E. Bachmann, and J. J. Oertli. 1991. The effect of salinity on light and dark $\mathrm{CO}_{2}$-fixation of salt-adapted and unadapted cell cultures of Atriplex and tomato. J. Exp. Botany 42: 531-535.

Rand, T. A. 1999. Effects of environmental context on the susceptibility of Atriplex patula to attack by herbivorous beetles. Oecologia (Berl.) 121: 39-46.

Rand, T. A. 2000. Seed dispersal, habitat suitability and the distribution of halophytes across a salt marsh tidal gradient. J. Ecol. 88: 608-621.

Rand, T. A. 2004. Competition, facilitation, and compensation for insect herbivory in an annual salt marsh forb. Ecology 85: 2046-2052.

Roitto, M., A. Markkola, R. Julkunen-Tiitto, T. Sarjala, P. Rautio, K. Kuikka, and J. Tuomi. 2003. Defoliationinduced responses in peroxidases, phenolics, and polyamines in scots pine (Pinus sylvestris L.) needles. J. Chem. Ecol. 29: 1905-1918.

SAS Institute. 2002. PROC user's manual, version 9.1. SAS Institute, Cary, NC.

Sharkey, T. D. 1985. Photosynthesis in intact leaves of $\mathrm{C}_{3}$ plants: physics, physiology and rate limitations. Bot. Rev. 51: 53-105.

Shen, Y., B. Du, W. Zhang, J. Zhang, and S. Chen. 2002. A $h C M O$, regulated by stresses in Atriplex hortensis, can improve drought tolerance in transgenic tobacco. Theor. Appl. Genet. 105: 815-821.

Tang, J. Y., R. E. Zielinski, A. R. Zangerl, A. R. Crofts, M. R. Berenbaum, and E. H. DeLucia. 2006. The differential effects of herbivory by first and fourth instars of Trichoplusia ni (Lepidoptera: Noctuidae) on photosynthesis in Arabidopsis thaliana. J. Exp. Botany. 57: 527-536.

Tscharntke, T., W. Boland, R. Dolch, and S. Thiessen. 2001. Herbivory, induced resistance, and interplant signal transfer in Alnus glutinosa. Biochem. Systemat. Ecol. 29: 1025-1047.

Ungar, I. A. 1996. Effect of salinity on seed germination, growth, and ion accumulation of Atriplex patula (Chenopodiaceae). Am. J. Botany. 83: 604-607.

Ungar, I. A. 1998. Are biotic factors significant in influencing the distribution of halophytes in saline habitats? Bot. Rev. 64: 176-199.

van Kooten, O., and J.F.H. Snel. 1990. The use of chlorophyll fluorescence nomenclature in plant stress physiology. Photosynth. Res. 25: 147-150.

Vickerman, D. B., M. C. Shannon, G. S. Banuelos, C. M. Grieve, and J. T. Trumble. 2002. Evaluation of Atriplex lines for selenium accumulation, salt tolerance and suitability for a key agricultural insect pest. Environ. Pollut 120: 463-473.

von Caemmerer, S. 2000. Biochemical models of lead photosynthesis. CSIRO Publishing, Victoria, Australia.

von Caemmerer, S., and G. D. Farquhar. 1981. Some relationships between the biochemistry of photosynthesis and the gas exchange of leaves. Planta 153: 376-387.

Wang, L., A. M. Showalter, and I. A. Ungar. 1997. Effect of salinity on growth, ion content, and cell wall chemistry in Atriplex prostrata (Chenopodiaceae). Am. J. Botany. 84: 1247-1255.

Wu, L., A. Enberg, and K. K. Tanji. 1993. Natural establishment and selenium accumulation of herbaceous plant 
species in soils with elevated concentrations of salinity and under irrigation and tillage practices. Ecotoxicol. Environ. Saf. 25: 127-140.

Zangerl, A. R., J. G. Hamilton, T. J. Miller, A. R. Crofts, K. Oxborough, M. R. Berenbaum, and E. H. de Lucia. 2002. Impact of folivory on photosynthesis is greater than the sum of its holes. Proc. Nat. Acad. Sci. U.S.A. 99: $1088-1091$.

Received for publication 28 April 2006; accepted 10 August 2006 